\title{
Geoffrey of Monmouth and Race
}

\author{
Coral Lumbley
}

\section{Introduction to Medieval Race}

Geoffrey of Monmouth's De gestis Britonum abounds with human collectivities which he variously identifies as nationes, gentes, and populi. An abbreviated list of the text's cast of collectivities includes Trojans, Britons, Romans, Saracens, Burgundians, Huns, Basques, Irish, Scythians, Picts, Scots, Flemings, Armoricans, Africans, Saxons, Normans, and Christians, a group that, for Geoffrey, is theoretically synonymous with the humanum genus, the "human race", as a whole. ${ }^{1}$ This capacious representation of Britain's history, in which the eponymous Britons develop a sophisticated civilization through interaction with a diverse set of peoples, revolutionized historical writing in Britain. We know that Geoffrey wrote for an elite Anglo-Norman audience in the early 113os, and that his work, shedding (fictional) light on the mysterious lost history of the Welsh, was wildly popular among Welsh, Anglo-Norman, and, eventually, English audiences. The socio-political agenda of Geoffrey's intervention in the Anglocentric histories of Britain available to Anglo-Norman newcomers in Britain, however, is less understood. Did Geoffrey's text serve to denigrate the Welsh or to elevate their status? Did Geoffrey support Anglo-Norman colonialism in Britain or did he critique it? Was Geoffrey Welsh, Anglo-Norman, or both, and how did his own identity inform his historiography? While these questions cannot be answered simply, we may better understand Geoffrey's intervention in the socio-political shifts of his time through analysis of the racial logics undergirding his work. ${ }^{2}$ Such an analysis reveals that Geoffrey

$1 \quad D G B$, iiii.64.276. D.K. Buell notes that "class, ethnicity, and gender are ... specifically singled out as the divisions overcome by redemption in Christ", but that this idea saw only theoretical development and little praxis. See Why This New Race: Ethnic Reasoning in Early Christianity, New York, 2005, p. x.

2 Geoffrey of Monmouth's career is an important touchstone for scholarship on medieval race. According to T. Hahn, "The Difference the Middle Ages Makes: Color and Race before the Modern World", JMEMS 31 (2001), 1-38, at p. 8, "Geoffrey of Monmouth's History of the Kings of Britain (1135), which has been called the most influential book written during the European Middle Ages, displaces English and Norman antagonisms onto the ancient clash of Britons and Germanic invaders, and in the process it renders racial antagonism a crucial component of any larger vision of natural history." Indeed, Hahn states that "the frameworks, the terms, 
contributes to Norman colonialism by establishing a system of race in which hybridization operates as a useful tool in empire-building. ${ }^{3}$ Simultaneously, he establishes a binary between a new European civilization and the old Roman world with its allies and re-orients both Saxon and Roman identities, grouping them with Eastern and African alterities to establish a new Eurocentric focus for British historiography.

The multilingual and multicultural milieu of 12th-century Britain necessitates scholarship which accounts for various systems of differentiation between peoples. ${ }^{4}$ Building upon the advent of medieval postcolonial studies, two systems of differentiation, those of ethnicity and of race, have recently entered the literary critical field with force. ${ }^{5}$ The use of ethnicity as an analytic category by which to study premodern texts is decidedly less controversial than that of race. Modern ethnicity operates as a horizontal system of human classification and refers to an individual's or group's ancestrally inherited cultural practices, including but not limited to religious practices, language/ dialect spoken, national origins/citizenship, dwelling modes and places, clothing and hairstyles worn, food preparation, and food consumption. Ethnicity is sometimes used as a synonym for race, but it is perhaps best characterized as one element of race, as I discuss below. ${ }^{6}$

The concept of a group of people lacking any ethnicity has permeated popular American thought, especially in Anglo-American circles. It was once

the very peoples devised by ... Geoffrey define specific and distinctive medieval engagements with race." See D. Kim, "Introduction to Literature Compass Special Cluster: Critical Race and the Middle Ages", Literature Compass 16:9-10 (2019), 1-16.

3 On the de/merits of various types of hybridities as contemporary and historical critical concepts, see J. Nederveen Pieterse, Globalization and Culture: Global Mélange, nnd ed., Lanham, 2009, pp. 97-101.

4 M. Chibnall, Anglo-Norman England, 1066-1166, Oxford, 1986, p. 208, identifies Geoffrey's time and place in history as messily multi-racial, a characterization which Hahn echoes in "Difference", p. 7 .

5 For foundational work on postcolonial studies, see F. Fanon, The Wretched of the Earth, trans. C. Farrington, New York, 1968; E.W. Said, Orientalism, London, 2003; and G.C. Spivak, "Can the Subaltern Speak?" in C. Nelson and L. Grossberg (eds.), Marxism and the Interpretation of Culture, London, 1988, pp. 271-316. For foundational work on medieval postcolonialism, see J.J. Cohen (ed.), The Postcolonial Middle Ages, New York, 2ooo; id., Hybridity, Identity, and Monstrosity in Medieval Britain: On Difficult Middles, New York, 20o6; id. (ed.), Cultural Diversity in the British Middle Ages: Archipelago, Island, England, New York, 2008; P.C. Ingham, Sovereign Fantasies: Arthurian Romance and the Making of Britain, Philadelphia, 20o1; and M.R. Warren, History on the Edge: Excalibur and the Borders of Britain, 1100-1300 (Medieval Cultures, 22), Minneapolis, 2ooo.

6 See R. Bartlett, The Making of Europe: Conquest, Colonization and Cultural Change 950-1350, Princeton, 1994, as well as Buell, Why This New Race. 
common for the term "ethnic people" or the slur "ethnics" to refer to minorities or people of color, in a problematic attempt to refer to peoples of color as one large group. This verbiage indicates that white "Caucasians" see themselves as lacking cultural practices or physiological traits which signify ethnicity. Despite this disavowal of ethnicity in some areas of the modern world, the category remains useful in a sociological sense, showing that self-identification can reveal useful perceptions about group identity while remaining potentially flawed in logic. Groups that fit into the category of "white Caucasian" (or white European with a specific set of assimilated cultural practices) but are distinguishable based on cultural practices include, for example, Irish Americans, Italian Americans, and German Americans. ${ }^{7}$ The horizontal category of ethnicity has been applied to medieval texts with relatively little controversy. ${ }^{8}$ For example, scholars have identified the Normans and the Saxons as two discrete ethnic groups and faced little argument. However, these groups were seen as hierarchically different by some medieval writers, including Geoffrey, troubling the modern concept of whiteness as a pan-ethnic, unified category in the Middle Ages.

Indeed, Dorothy Kim has shown that what we call ethnicity also seems to operate as a component of medieval race itself. ${ }^{9}$ Rather than removing the subject of ethnicity from the study of medieval race, or ignoring race in favor of ethnicity, we can treat ethnicity as a collection of embodied cultural givens (including social systems such as government, codes of conduct, and economies) which were used by medieval thinkers to develop and enforce social hierarchies based on embodied essentialisms, or race. ${ }^{10}$ For example, Welsh dependence on pastoralism and transhumance was used by Anglo-Norman

R.F. Kennedy, C.S. Roy, and M.L. Goldman (eds.), Race and Ethnicity in the Classical World: An Anthology of Primary Sources in Translation, Indianapolis, 2013, p. xiii, differentiate between modern race and modern ethnicity: 'In the post-Enlightenment world, a 'scientific,' biological idea of race suggested that human difference could be explained by biologically distinct groups of humans, evolved from separate origins, who could be distinguished by physical differences, predominantly skin color. Ethnicity, on the other hand, is now often considered a distinction in cultural practice within the same race." L. Ramey, Black Legacies: Race and the European Middle Ages, Gainesville, FL, 2014, p. 25, takes a similar viewpoint, suggesting that that "race" refers to "a group that shares some socially selected physical traits, as opposed to 'ethnicity, which is defined by socially selected cultural traits". On race-making, "ethnic" whiteness, and modern Irish, see N. Ignatiev, How the Irish Became White, New York, 1995 (repr. 2009).

8 See W.C. Jordan, “Why 'Race'?” JMEMS 31:1 (2001), 165-74 and M. Eliav-Feldon, B. Isaac, and J. Ziegler (eds.), The Origins of Racism in the West, Cambridge, 2009.

9 D. Kim, "Reframing Race and Jewish/Christian Relations in the Middle Ages", transversal: Journal for Jewish Studies, 13:1 (2015), 52-64.

10 Buell, Why This New Race, p. x, uses the two terms interchangeably in a conscious provocation of how modern readers think about Christianity as an identity. R. Bartlett, "Medieval 
chroniclers to scaffold beliefs and practices placing the English as the supreme race of Britain. What would be considered elements of ethnicity today (heavy dependence on livestock instead of agrarianism, consumption of meat and milk rather than bread, non-participation in seasonal agricultural activities) were racialized (essentialized and used as justification for hierarchization) by Anglo-Norman and English writers.

Race as an analytic category for the Middle Ages has faced considerable resistance by some medievalists, many of whom voice desire to avoid presentism and anachronism. ${ }^{11}$ In the modern world, race as a social category is frequently signified by and interpreted according to physiognomic traits, especially skin color and genetic descent, making modern critical race studies seemingly difficult to apply to premodern texts. Indeed, the case against medieval race is founded upon the entirely accurate fact that modern race is largely the product of post-medieval phenomena. Key events in the formation of modern race include the trans-Atlantic slave trade and African diaspora, Enlightenment thought, global colonialism, and pseudo-scientific rationalization of hierarchical classifications of genetic traits such as skin color. Indeed, modern race is not a horizontal system but a vertical one, couched in the notion that an individual's external appearance reflects one's blood and therefore one's ability to function in an ideal (frequently Anglo American), "modern" society. Therefore, careless application of modern notions of race to the Middle Ages can generate anachronistic readings. To put it simply, modern whiteness is not identical to medieval forms of whiteness; modern blackness is not identical to medieval ideas of blackness. ${ }^{12}$

However, Geraldine Heng's paradigm-shifting work, as well as the work of many scholars of color in both print and digital spaces, ${ }^{13}$ has shown that hierarchical views of peoples based on cultural practices and embodied characteristics, or at least perceptions of essentialized, embodied characteristics, existed in the Middle Ages; thus, "race is a structural relationship for the articulation and management of human differences, rather than a substantive content."14

and Modern Concepts of Race and Ethnicity", JMEMS 31 (2001), 39-56, at pp. 41-42, also treats them as synonyms.

11 See M. Chibnall, "'Racial' Minorities in the Anglo-Norman Realm", in S.J. Ridyard and R.G. Benson (eds.), Minorities and Barbarians in Medieval Life and Thought, Sewanee, 1996, pp. 49-62, at p. 49 .

12 See C. Whitaker, "Black Metaphors in the King of Tars", JEGP 112:2 (2013), 169-93; id., "Race-ing the dragon: the Middle Ages, Race and Trippin' into the Future", postmedieval 6:1 (2015), 3-11; Ramey, Black Legacies; and Eliav-Feldon et al. (eds.), Origins of Racism.

13 See J. Hsy and J. Orlemanski, "Race and Medieval Studies: A Partial Bibliography", postmedieval 8:4 (2017), 500-31.

14 G. Heng, The Invention of Race in the European Middle Ages, Cambridge, 2018, p. 19. Also see the argument for "race" instead of "otherness" or "prejudice" on p. 27. J. Tanner, "Race and 
Varieties of race proliferated in the premodern world, with Heng demonstrating that religious, cartographic, colonial, and epidermal racial systems manifest across the biopolitics and sociopolitics of medieval time and space. ${ }^{15}$

We must also recognize that, as modern race, white supremacy, and ethnonationalism are deeply significant issues within academic and popular discourse communities, medieval scholarship must generate understandings of medieval race. ${ }^{16}$ This is not to say that we can apply modern critical race theory to medieval circumstances in a seamless or simple fashion. Just as modern concepts such as ethnicity, class, gender, and sexuality must be adjusted when applied to medieval contexts (which certainly contain social dynamics related to these modern systems of human categorization), so must medieval critical race develop as a study related to, though not synonymous with, modern critical race. It is for these reasons that medieval race can indeed serve as a useful category in medieval scholarship.

It follows, then, that there are situations in which race ought to be used as a medieval category. Just as modern racial discourse is founded upon notions of blood-based group identity, as evidenced in the "one-drop rule" in the United States, so do medieval writers look to blood-based identity in classifications of people. Just as race today is mainly treated as being embodied and corporeal (located mainly in recognizable skin color, hair color and texture, facial characteristics, and other physiological traits), so is medieval race deeply corporeal. For medieval writers, race could be defined through the theory of

Representation in Ancient Art: Black Athena and After", in D. Bindman and H.L. Gates, Jr. (eds.), The Image of the Black in Western Art, new ed., Cambridge, MA, 2010, pp. 1-40, at p. 15, notes that that "modern Euro-American 'scientific' racism is just one type of racism, and it is analytically unhelpful to treat this single historically specific model of racism as a conceptual norm." To do so implies that "modern Euro-American racism is somehow, in contrast to its classical antique counterparts, genuinely intellectually coherent and scientifically well grounded."

15 Heng, Invention, p. 27.

16 See S. Lomuto, "White Nationalism and the Ethics of Medieval Studies", In the Middle, 5 December 2016, <http://www.inthemedievalmiddle.com/2016/12/white-nationalismand-ethics-of.html> (accessed 26 May 2019) and "Public Medievalism and the Rigor of Anti-Racist Critique", In the Middle, 4 April 2019, <http://www.inthemedievalmiddle. com/2019/o4/public-medievalism-and-rigor-of-anti.html> (accessed 26 May 2019); D. Kim, "Teaching Medieval Studies in a Time of White Supremacy", In the Middle, 28 August 2017, <http://www.inthemedievalmiddle.com/2017/08/teaching-medievalstudies-in-time-of.html > (accessed 26 May 2019) and Digital Whiteness \& Medieval Studies, Leeds, 2019; M. Rambaran-Olm, "Misnaming the Medieval: Rejecting 'Anglo-Saxon' Studies", History Workshop, 4 November 2019 <http://www.historyworkshop.org.uk/ misnaming-the-medieval-rejecting-anglo-saxon-studies/> (accessed 13 February 2020); and N. Lopez-Jantzen, "Between Empires: Race and Ethnicity in the Early Middle Ages", Literature Compass 16:9-10 (2019), 1-12. 
geohumoralism, the theory of peoples receiving their physiognomic and humoral traits from their natural environments. Isidore's Etymologies codified the work of Aristotle and Galen for a medieval audience, stating that "[p]eople's faces and coloring, the size of their bodies, and their various temperaments correspond to various climates. Hence we find that the Romans are serious, the Greeks easy-going, the Africans changeable, and the Gauls fierce in nature and rather sharp in wit, because the character of the climate makes them so."17 Isidore also transmits the concept that races form by taking upon themselves the characteristics of their geographies. In fact, "Some suspect that the Britons were so named in Latin because they are brutes. Their nation is situated with the Ocean, with the sea flowing between us and them, as if they were outside our orbit."18

Setting geohumoralism to one side, the argument has been made that medieval race was merely religious difference. However, Geraldine Heng reminds us that modern race is increasingly located in religion, with re-emergences of anti-Semitism, despite many Jewish people being classified as racially white, and Islamophobia becoming ideological standards in the political policies of Christian-majority countries. As medieval hierarchical organizations of peoples were frequently based on religion, the gap between modern and medieval race is diminishing. ${ }^{19}$

Ultimately, we would do well to make medieval race a point of deeper investigation. Because the hierarchical classification of peoples based on corporeal and cultural practices is an ageless phenomenon, the study of race should be as well. Claims of anachronism may be rooted in good faith understandings of how modern race works; however, these claims ultimately serve only to foreclose vital discussions about how humans have divided and ranked one another throughout time. If discussions of medieval race are shut down before they have begun, valuable knowledge about the social matrices of the medieval world is simply rejected. Medieval race may differ from modern race, but premodernists can certainly participate in the academy's recuperation of histories

17 Isidore of Seville, Etymologies Ix.ii.105, ed. W.M. Lindsay, Isidori Hispalensis Episcopi Etymologiarum sive Originum Libri XX, 2 vols., Oxford, 1911 (repr. 1989): "Secundum diversitatem enim caeli et facies hominum et colores et corporum quantitates et animorum diversitates existunt. Inde Romanos graves, Graecos leves, Afros versipelles, Gallos natura feroces atque acriores ingenio pervidemus, quod natura climatum facit", Isidore of Seville, Etymologies, trans. S.A. Barney, W.J. Lewis, J.A. Beach, O. Berghof, and M. Hall, The Etymologies of Isidore of Seville, Cambridge, 2006.

18 Isidore of Seville, Etymologies Ix.ii.102, ed. Lindsay: "Brittones quidam Latine nominatos suspicantur, eo quod bruti sint, gens intra Oceanum interfuso mari quasi extra orbem posita. De quibus Vergilius (Ecl. I, 66): Toto divisos orbe Britannos", trans. Barney et al.

19 See G. Heng, Empire of Magic: Medieval Romance and the Politics of Cultural Fantasy, New York, 2001, p. 12. Heng's observations have become increasingly relevant over time. 
of race throughout time. Toni Morrison's 1992 call to change is still relevant today. There is a racial, academic problem in that "in matters of race, silence and evasion have historically ruled literary discourse"; indeed, claims of anachronism resonate with the problem of silence that Morrison identifies. ${ }^{20}$ Fear of anachronism is partially responsible for the problem of scholarly evasion of the issue of race, as is concern about re-entrenching modern racist systems. ${ }^{21}$ Ultimately, this fear impoverishes medieval scholarship more than it benefits our academic enterprise, which must account for the social realities of racism and race in both modern and medieval ages. ${ }^{22}$

Geoffrey of Monmouth's intellectual milieu included both learned, theological considerations of race codified by Isidore and situationally-specific representations of race by his contemporaries. It has long been acknowledged that Geoffrey's personal investment in the racial politics of Britain seems to have stemmed from his own hybrid identity. ${ }^{23}$ Geoffrey has been identified as ethnically hybrid, a Norman with Welsh or Breton descent and/or affiliation; although little is known of his family, he has been treated as a border figure, hailing from Monmouth in the Welsh Marches. ${ }^{24}$ Scholarship has long speculated that Geoffrey was, in fact, Breton, as his work shows great admiration for the deeds of ancient Bretons, who are originally Britons and thus Trojans, sharing

20 T. Morrison, Playing in the Dark: Whiteness and the Literary Imagination, New York, 1992, p. 10.

21 Proponents of using the term in scholarship note that its ability to induce discomfort is part of its usefulness: Buell, Why This New Race, p. 21, argues that "because our interpretive models for studying the ancient past have been formulated and revised within racist cultures, we need to keep the term active so as to be able to examine how our interpretive models encode, and thus perpetuate, particular notions about race." J.J. Cohen, "Race", in M. Turner (ed.), A Handbook of Middle English Studies, Hoboken, 2013, pp. 109-22, at p. 116, notes that "taxonomies of differentiation are hierarchical - not equalizing", and thus "race captures the differentiation of medieval peoples far better than more innocuous terms." See D. Armenti and N.I. Otaño Gracia, "Constructing Prejudice in the Middle Ages and the Repercussions of Racism Today", Medieval Feminist Forum 53:1 (2017), 176-201. See also the ongoing work of the Medievalists of Color collective, housed digitally at $<$ medievalists ofcolor.com> (accessed 18 April 2019).

23 On Geoffrey's identity, see the Introduction to this volume.

24 As Bartlett has established, Anglo-Norman creation of the Marches of Ireland and Wales brought together senses of identity tied to French, English, Flemish, Welsh, Irish, and Latin languages. Geoffrey's linguistic affinities are far easier to comprehend than his ethnic ones, to the extent that ethnicity and language can viewed as separate. See R. Bartlett, Gerald of Wales, 1146-1223, Oxford, 1982, p. 14. 
equally in the admirable descent of the peoples of Cornubia (Cornwall, named for the valiant Corineus), Loegria (England, for Locrinus), Kambria (Wales, for Kamber), and Albania (Scotland, for Albanactus). ${ }^{25}$ Whether Welsh, Breton, or even Cornish, Geoffrey emphasizes the kinship of Breton and Welsh peoples and gives us evidence for his investment in both cultures. Thus, whether Welsh or Breton, Geoffrey's hybrid identity is a key element of his authorial identity for both medieval and modern scholars. It is little surprise that racial and ethnic identities manifest as key issues in Geoffrey's work.

Geoffrey's own intervention in the discourse of race in Britain is of massive significance, considering how influential his $D G B$ became in the centuries following its completion. Not only did the text establish a founding mythology for Britain, but it established conventions of the discourse of race. Ultimately, Geoffrey develops a new model of race in the deep history of Britain, thus innovating a system for a new, postcolonial Britain. ${ }^{26}$

Geoffrey's representation of race departs from his models in that he is highly interested in the malleable and generative nature of race. Rather than providing a rote account of how the world's peoples separated from one another and crystallized into their current states, his narrative is about the creative possibilities of hybridity. Of course, there are caveats to this statement: some races are more prestigious than others, and the ability to effect organized colonization is a key elevating factor in a group's status. For Geoffrey, race is highly malleable, but still reveals the impossibility for some peoples (such as Africans, Huns, Goths, and Saxons) to integrate into the heights of European civilization. ${ }^{27}$ Geoffrey's concern with what constitutes correct forms of colonization in his narrative reveals motivation for why he portrays race as he does. In providing admirable models of ethnic hybridity in ancient Britain, Geoffrey paves the way for himself and the Anglo-Norman elite, including his patron, Robert of Gloucester, to push forward the colonizing efforts begun by Henry I. In praising the glorious possibilities of hybridity, Geoffrey campaigns for a

25 Tatlock, $L H B$, pp. 19 and 443, argues strongly for Geoffrey's Breton heritage. See Joshua Byron Smith's Introduction to this volume for an overview of this debate.

26 Although many medieval writers display disbelief or discomfort with racial mixing, Geoffrey's $D G B$ seems to be somewhat of an outlier. J.J. Cohen in "Hybrids, Monsters, Borderlands: The Bodies of Gerald of Wales", in id. (ed.), The Postcolonial Middle Ages, pp. 85-104, at p. 96, points to the work of Gloria Anzaldúa for a model of medieval hybridity; G. Anzaldúa, in Borderlands/La Frontera: The New Mestiza, San Francisco, 1987; H.K. Bhabha, The Location of Culture, London and New York, 1994.

27 S. Kinoshita, Medieval Boundaries: Rethinking Difference in Old French Literature, Philadelphia, 2006, p. 5, argues that Geoffrey's "representations of alterity were notably more fluid and less marked by the racializing discourses typical of later centuries than we sometimes assume". 
specific brand of colonialism, one which uses intermarriage and cultural appropriation to facilitate assimilation..$^{28}$ Arthur's wondrous square loch in Moray, Scotland is exceptional because its inhabitants are fully segregated; four types of fish swim there, but never stray from their own corners. ${ }^{29}$ For Geoffrey, the notion of living beings maintaining the integrity of their own group identities throughout time is a wondrously improbable concept.

Following Bede, Geoffrey sets up his narrative by listing the quinque ... populis, "five peoples", who inhabit Britain, the insularum optima, "best of islands": the Normannis ... atque Britannis, Saxonibus, Pictis, et Scotis, "Normans and Britons, Saxons, Picts, and Scots" ${ }^{30}$ Rather than listing five languages like Bede and Henry of Huntingdon, he lists five peoples. This choice allows him to maintain Bede's five-part form while shifting focus from languages to types of people occupying Britain and to exchange the cosmopolitan Latin language for the Norman people. ${ }^{31}$ Also significant is the fact that for Bede, the Saxons were the group holding pride of place as the first group to be listed, whereas for Geoffrey it is the Normans. If Geoffrey's affiliation and alliances were not made sufficiently clear in his Prologus, they are in the "Descriptio Insulae".

Almost instantly after presenting the current races of Britain, Geoffrey begins his narrative with an account of Aeneas, pulling the current affairs of Britain into the classical world. While Aeneas's descendants have found a home in Italy, the descendants of Priam are in thrall to the Greeks when Brutus finds himself in their midst. Like a new Moses, Brutus is viewed as a salvific figure to the enslaved Trojans, who "began to flock to him, asking that he be their leader and free them from their bondage to the Greeks". ${ }^{22}$ Geoffrey's first

28 As S. Kinoshita observes in "Translatio/n, Empire, and the Worlding of Medieval Literature: the Travels of Kalila wa Dimna", Postcolonial Studies 11:4 (2008), 371-85, at p. 122, imperialism hybridizes itself as a means of spreading and consolidating power.

$29 D G B$, ix.150.179-83: "Erat quippe haut longe illinc, latitudinem habens uiginti pedum eademque mensura longitudinem cum quinque pedum altitudine; in quadrum uero siue hominum arte siue natura constitutum, quatuor genera piscium infra quatuor angulos procreabat, nec in aliqua partium pisces alterius partis reperiebantur", "Quite near [another loch], it was twenty feet wide, twenty feet long and five feet deep; square in shape, either by the hand of man or naturally, it supported in its four corners four species of fish, none of which ever strayed into the space of the other three."

$30 \quad D G B$, i.5.42-44.

31 Like Bede, Henry of Huntingdon categorizes Britain's peoples by language: "Quinque autem linguis utitur Britannia, Britonum uidelicet, Anglorum, Scotorum, Pictorum et Latinorum", "Five languages are in use in Britain: those of the Britons, the English, the Scots, the Picts, and also of the Latins." See Henry of Huntingdon, History of the English i.8, ed. and trans. D. Greenway, Henry, Archdeacon of Huntingdon: Historia Anglorum. The History of the English People, Oxford, 1996, pp. 24-25.

$32 \quad D G B$, i.7.76-77: "coeperunt ad eum confluere, orantes ut ipso duce a seruitute Graecorum liberarentur." 
hybrid hero emerges here as Brutus's lieutenant Assaracus. Assaracus is a nobilissimus iuuenis, "most noble youth", who is the son of a Greek man and Trojan woman. ${ }^{33}$ Being sympathetic to the Trojan cause, this figure becomes a pivotal figure in Briton history. Assaracus's doubled, or hybrid, identity results in his poor treatment at the hands of the Greeks:

For he was in dispute with his brother over three castles that their father had granted to Assaracus on his deathbed, which his brother was trying to take from him because his mother had been a concubine. The brother by contrast was Greek on both sides and had induced the king and the other Greeks to support his faction. ${ }^{34}$

This passage portrays Greece not merely as a multiethnic place, but as a multiracial one, where one group of people have posited inborn racial superiority over another. Assaracus's mother comes from a low caste, and not merely because she is a prostitute. Her Greekness and her status as a sex worker combine to give her son a racial identity a cut below that of his full-blooded Greek brother. Geoffrey's portrayal of Assaracus as a "most noble youth" calls the Greek perception of hybridity as negative into question. Rather than diminishing his status, Assaracus's doubled identity makes him uniquely qualified to take up the vital task of leading Trojans to a new and better land. Thanks to Assaracus's assistance, Brutus executes a massively successful military ambush against the Greeks, freeing the Trojans from their bondage. The Trojans make their way westward, garnering honorable victories against various groups as they travel and land at the island of Albion, "which was inhabited by none except a few giants". ${ }^{35}$

Alternating periods of strife and peace between Britain and Rome occupy a significant portion of the $D G B$, and are important moments for Geoffrey's development of his model of race. Even though Julius Caesar acknowledges the ancient kinship between Romans and Britons, calling the Britons his own cognati, "cousins", he orders the rulers of Britain to submit to his supremacy, just like ceterae ... gentes, "other nations". ${ }^{36}$ According to Caesar, the Britons

\footnotetext{
$33 D G B$, i.7.79-80.

$34 D G B$, i.7.80-85: "Ex Troiana namque matre natus erat fiduciamque in illis habebat maximam ut auxilio eorum inquietudini Graecorum resistere quiuisset. Arguebat enim eum frater suus propter tria castella quia sibi moriens pater donauerat et ea auferre conabatur quia ex concubina natus fuerat. Erat autem frater patre et matre Graecus asciueratque regem ceterosque Graecos parti suae fauere."

$35 D G B$, i.21.453-54: "quae a nemine, exceptis paucis gigantibus, inhabitabatur".

$36 \quad D G B$, iiii.54.14; 13 .
} 
have fallen from their glorious Trojan origins: "Unless I am mistaken, they are no longer our equals and have no idea of soldiering, since they live at the edge of the world amid the ocean."37 For Caesar, the Britons' ethnic identity has shifted fundamentally thanks to their relocation away from the center of human civilization. Therefore, they are racially inferior to the Romans, who have maintained the higher racial status of the Trojans. Geoffrey quickly shows that Caesar is mistaken, elevating the Britons to the very status which Caesar believes they have lost.

King Cassibellaunus refutes Caesar's accusation and shames the emperor for his belief in the Britons' racial degeneration, saying, "Your request disgraces you, Caesar, since Briton and Roman share the same blood-line from Aeneas, a shining chain of common ancestry which ought to bind us in lasting friendship." ${ }^{38}$ Cassibellaunus goes on to prove his worth by successfully defending Britain from the yoke of Rome, humiliating Caesar in military defeat. Caesar retreats to Rome, knowing he would not survive another engagement with such a feroci populo, "fierce people". ${ }^{39}$ When Caesar returns two years later, Cassibellaunus routs him a second time. This series of victories demonstrate the valiant nature of the Britons, a nature which Geoffrey's audience would not have attributed to the modern Welsh. ${ }^{40}$ At this point in time, the Britons and the Romans are equally prestigious. No external force can topple their power; indeed, it takes internal strife to bring Britain under the sway of the Roman empire.

$37 \quad D G B$, iiii.54.9-10: "Sed nisi fallor ualde degenerati sunt a nobis nec quid sit milicia nouerunt, cum infra occeanum extra orbem commaneant."

$38 \quad D G B$, iiii.55.23-26: "Opprobrium itaque tibi petiuisti, Caesar, cum communis nobilitatis uena Britonibus et Romanis ab Aenea defluat et eiusdem cognationis una et eadem catena praefulgeat, qua in firmam amicitiam coniungi deberent."

$39 \quad D G B$, iiii.58.92.

40 For studies of negative portrayals of the Welsh in Norman Latinate circles of Britain, see M.A. Faletra, Wales and the Medieval Colonial Imagination: The Matters of Britain in the Twelfth Century, New York, 2014; R. Kennedy and S. Meecham-Jones (eds.), Authority and Subjugation in Writing of Medieval Wales, New York, 2008; A. Plassmann, "Gildas and the Negative Image of the Cymry", cMcs 41 (2001), 1-15; J. Gillingham, The English in the Twelfth Century; and W.R. Jones, "England Against the Celtic Fringe: A Study in Cultural Stereotypes", Journal of World History 13:1 (1971), 155-71. For a discussion of how classical representations of a universal model of cultural development were used as secular justification for Norman expansionism, see S. Khanmohamadi, In Light of Another's Word: European Ethnography in the Middle Ages, Philadelphia, 2013. Of course, expansionism could result in coexistence, whether peaceful or tense; see R.R. Davies, "Race Relations in Post-Conquest Wales: Confrontation and Compromise", Transactions of the Honourable Society of Cymmrodorion (1974-75), 32-56. 
After the conversion, the rule of the island comes into question, threatening to throw Britain's government into disarray. The man who emerges victorious from this complication is the second of Geoffrey's conspicuously heroic hybrids: Maximianus. When the aging king Octavius must select an heir, having no son of his own, an advisor suggests that Octavius give his filiamque ei cum regno, "his daughter and crown", to Maximianus. ${ }^{41}$ According to Geoffrey, this suggestion is ideal, as

Maximianus had a British father ... while his mother and his nation were Roman, so that he was of royal blood on both sides. Hence Caradocus could promise peace, since he knew that Maximianus' claim to Britain rested both on imperial descent and British birth. ${ }^{42}$

Geoffrey emphasizes Maximianus's royal descent, but calls special attention to his mixedness, which makes him uniquely qualified for kingship. Although Romans and Britons share ancestors, they have developed into new races, separated by a deep rift which can only be mended by Maximianus. On his deathbed, Octavius is reassured by an advisor who says, "See now, God has deigned to send you this young man, of Roman blood and descended from the British royal family"43 By logic of his hybrid descent, Maximianus will ensure peace for the Britons.

Both Maximianus and Assaracus are hybrids whose qualifications are largely those of blood; because they have doubled parentage, they seem to be doubly useful to the Britons' enterprise of nation-building. The $D G B$ 's focus on the history of Geoffrey's home island and its original occupants building a civilization at the edge of world means that its portrayal of hybridity focuses on how a doubled identity can solidify political and military power. Indeed, our two key hybrids intervene in turning points in the political history of Britain; Assaracus facilitates the Britons' exodus from Greece and their subsequent transformation from a race of slaves to a sovereign nation. Maximianus transforms Britain from a province of the Roman empire to a conquering nation in its own right. ${ }^{44}$

$41 \quad D G B$, v.81.203.

$42 \quad D G B$, v.81.203-o8: "Erat autem patre Brittannus ... ipsum genuerat; matre uero et natione Romanus ex utroque sanguine regalem ferebat procreationem. Iccirco igitur stabilitatem pacis promittebat quia sciebat illum et ex genere imperatorum et ex origine Britonum ius in Britanniam habere."

$43 \quad D G B$, v.83.287-88: "Ecco ergo tibi dignatus est subuectare Deus iuuenem istum, et ex genere Romanorum et ex regali prosapia Britonum creatum.”

44 See M.J. Curley, “Conjuring History: Mother, Nun, and Incubus in Geoffrey of Monmouth's Historia Regum Britanniae”, JEGP 114:2 (2015), 219-39, at p. 237, for Merlin as a positive hybrid figure. 
Because Geoffrey has set up a model of positive hybridity, the undesirable results of racially homogenizing policies come as little surprise in Book $\mathrm{V}$ of the $D G B$. In fact, an attempt to engineer a settlement upon the principle of racial purity results in one of the text's most tragic events. Having grown bored in his kingdom, the king sails to conquer Armorica (Brittany) with Octavius's nephew Conanus. Maximianus pledges to create a new Britain for Conanus, saying, "I shall make you the ruler of this kingdom; we shall drive out its inhabitants, and it will be another Britain, occupied by our people."45 Lust for riches corrupts the noble king, whose conquering policies are unnecessarily cruel and involve slaughtering all men of the lands he conquers. He pauses only to undertake the settler colonialist occupation of Armorica, filling it with a Britannico populo, "British population", which he presents to Conanus. ${ }^{46}$

Conanus seeks to continue the project of engineering a racially pure colony by rewarding his British soldiers with wives: "To avoid intermarriage with the French he ordered that women should come from the island of Britain to be their brides." ${ }^{47}$ Conanus instructs the regent king of Britain, Dionotus, to export women to the colony, hoping that Dionotus's beautiful daughter Ursula will be included in the shipment. ${ }^{48}$ The plan to prevent a hybrid generation of Britons is carried out without delay. Dionotus "gather[s] 11,00o noblemen's daughters, as well as sixty thousand girls of common birth" and ships them from London to Armorica. ${ }^{49}$

The Britons' conquest of Armorica occurs under unsavory circumstances, but Conanus's attempt to import a wholesale shipment of British wives worsens the situation. Most of the women object to the arrangement, preferring virginity or their parentes et patriam, "parents and country", to seeking wealth through marriage in the new Britain..$^{50}$ Geoffrey notes that their various preferences soon become moot, since the ships are swiftly wrecked by storms. Most women drown and "[t]he few women who escaped the danger were driven to foreign islands, where they were butchered or enslaved by an unknown

$45 D G B$, v.84.324-26: "Promouebo etenim te in regem regni huius, et erit haec altera Britannia, et eam ex genere nostro expulses indigenis repleamus."

$46 \quad D G B, \mathrm{v} .86 .349$.

$47 \quad D G B$, v.87.365-66: "Et ut nullam commixtionem cum Gallis facerent, decreuit ut ex Britannia insula mulieres uenirent quae ipsis maritarentur."

48 This episode is an adaptation of the legend of St Ursula and the 11,o1o virgins. In the legend, Ursula is sent across the sea to wed the pagan Attila, alongside other reluctant maidens. A shipwreck results in their attempted rapes and deaths at the hands of Huns. See Tatlock, $L H B$, pp. $236-41$.

$D G B$, v.88.373-74: "collegit per diuersas prouintias filias nobilium numero undecim milia, de ceteris ex infima gente creatis sexaginta milia." 
people." ${ }^{51}$ The survivors refuse sex with foreign soldiers they encounter and are killed. Little known to the women themselves, their killers are revealed to have been Hun and Pictish forces, sent by Rome to eradicate British invaders of the Continent. The very women meant to serve as vessels for a pure British civilization are subjected to horrific deaths in foreign lands. Rather than kill the British men, the Huns and Picts eradicate the possibility of British racial homogeneity in Armorica. The text leaves the audience to assume that the British inhabitants of Armorica intermarry with the French women of the area. Given Geoffrey's consistent praise of the Bretons, it seems that this intermarriage yielded fortunate results. ${ }^{52}$ The glorious career of Maximianus becomes a lesson about the impossibility of racial purity in expansionist projects, with the narrative hinging upon the racialized villainy of Huns and Picts, two peoples whom Geoffrey excludes entirely from the possibility of incorporation.

The culminating point of Geoffrey's colonialist agenda, favorable as it is toward the idea of mixedness, is in the court of King Arthur itself. Although Arthur ensures that his own royal British family members are restored to their ancestors' seats as kings of Britain, he desires Britain to become a cosmopolitan center. Thus he "began to increase his household by inviting all the best men from far-off kingdoms and conducted his court with such charm that he was envied by distant nations". ${ }^{53}$ Arthur fosters ethnic diversity, not racial seclusion, within his court, resulting in global fear and respect for his excellence. In turn, Arthur sets and fulfills the goal of uniting one third of the world, Europe, under his rule, ${ }^{54}$ with his success illustrated by the sheer number of nobles present at his coronation at Caerleon. Lords from the whole of Britain, Ireland, Iceland, Gotland, the Orkneys, Norway, Denmark, Flanders,

$5^{1} \quad D G B$, v.88.386-87: "Quae uero tantum periculum euaserunt appulsae sunt in barbaras insulas et ab ignota gente siue trucidatae siue mancipatae."

52 The Welsh account of this tale provides a more explicit, and disturbing, ending to the story of Brittany's founding. See Breudwyt Maxen Wledic, ed. B.F. Roberts, Dublin, 2005, pp. 10-11; The Mabinogion, trans. S. Davies, Oxford, 2007, pp. 103-10, at p. 110.

$53 D G B$, ix.154.225-27: "inuitatis probissimis quibusque ex longe positis regnis, coepit familiam suam augmentare tantamque faceciam in domo sua habere ita ut aemulationem longe manentibus populis ingereret."

$54 D G B$, ix.154.229-36: "Denique, fama largitatis atque probitatis illius per extremos mundi cardines diuulgata, reges transmarinorum regnorum nimius inuadebat timor ne inquietatione eius oppressi nationes sibi subditas ammitterent ... Cumque id Arturo notificatum esset, extollens se quia cunctis timori erat, totam Europam sibi subdere affectat", "As his reputation for generosity and excellence spread to the farthest corners of the world, kings of nations overseas became very frightened that he would attack and deprive them of their subjects ... When Arthur learned of this, he exulted at being universally feared and decided to conquer all Europe." 
Boulogne, Normandy, Anjou, Armorica, and the twelve peers of France attend, with all peoples present expressing their love for Arthur and his world-famous largesse. ${ }^{55}$ The sophistication and ostentation of the coronation celebrations are apparently indescribable, but Geoffrey does provide one detail of the feast, reminding readers of why the Britons are deserving of political supremacy and the love of their conquered subjects. Arthur's court observes the "old Trojan custom" of holding separate feasts for men and women. ${ }^{56}$ This fact, presented as a bit of historical curiosity for Geoffrey's readers, has little consequence for the narrative. It serves mainly to recall the glorious ancestry of the British people, an ancient race deserving of admiration and study.

Geoffrey's admirable hybrid figures and the diversification of Arthur's court through his conquest of Europe suggest that the $D G B$ represents race as malleable in the service of an imperial agenda. At Arthur's court, racial difference becomes a non-issue in a unified Europe where all peoples serve Arthur without reservation. However, Geoffrey's very description of peace is fraught with the specters of those not present at the joyous events at Caerleon. According to the $D G B$, some populi seem to exist outside the pale. While racial difference can be overcome and even deployed to individual or group advantage through hybridity, some peoples exist outside the acceptable range of racial difference.

\section{The Limits of Hybridity}

The crowning at Caerleon includes a wide range of peoples, but Spain emerges as the point of delimitation for Arthur's empire. According to Geoffrey, "there was no prince worth his salt this side of Spain who did not answer such a call" to the high court in Britain. ${ }^{57}$ This geographical limit reveals a Eurocentric focus to Geoffrey's narrative. The $D G B$ is the tale of British supremacy over one third of the tripartite world, with Asia and Africa remaining in the distance beyond Spain. The text's focus on Britain's history and the relationships between European peoples means that, for Geoffrey, this piece is a form of self-definition. This definitional mode necessitates the use of alterities; while Geoffrey's colonialist narrative supports multiethnic scenarios as a solution to

\footnotetext{
$55 \quad D G B, \mathrm{ix} .156 .306-55$.

$5^{6} \quad D G B$, ix.157.375-76: "antiquam namque consuetudinem Troiae".

$57 \quad D G B$, ix.156.353-54: "non remansit princeps alicuius precii citra Hispaniam quin ad istud edictum ueniret." Geoffrey's multiple negative associations with Spain diverge dramatically from Isidore's complimentary description of his homeland. See Isidore of Seville, History of the Kings, trans. G. Doninini and G.B. Ford, Jr., Isidore of Seville's History of the Kings of the Goths, Vandals, and Suevi, Leiden, 1966, pp. 1-2.
} 
racial hostilities, representations of Asian and African influences emerge as convenient narrative Others for British history. Furthermore, Geoffrey innovates a history linking the Saxons to non-European alterity, establishing them as outsiders of Arthur's glorious European empire.

The issues of the conspicuous absence of non-European peoples at Arthur's crowning is soon resolved when a messenger from the Roman Lucius Hiberius arrives, demanding tribute. In response, Arthur assembles a pan-European army and marches to Rome where he meets Lucius's army of African and Asian kings, including forces from Greece, Africa, Spain, Parthia, Media, Libya, Iturea, Egypt, Babylon, Bithynia, Phrygia, Syria, Boetia, and Crete. ${ }^{58}$ Lucius's army comes from the "other" side of Spain, from which no princes had come to Arthur's court. The $D G B$ 's Eurocentric focus means that this army is not defined, but operates as an intimidating force of 460,100 soldiers. ${ }^{59}$ Rather than provide ethnographic descriptions of this non-European, threatening army, Geoffrey deploys a giant to stand in for the racial alterities which Arthur faces. Echoing the duel with Frollo, whose Gaulish forces lurk behind him, Arthur duels a racialized figure in the form of a giant while Lucius's army assembles in the distance. ${ }^{60}$

It has come to be widely theorized that racial difference was popularly represented as what modern scholarship might call a difference in species; thus, a monstrous, or gigantic, body often stands in for a racially marked body. ${ }^{61}$ Geoffrey's giants operate as racialized Others of various identifications, with the defeat of the giants signifying British triumphs over unassimilable difference. The first fact that we learn about the magnitudinis gigantem, "huge giant", is that he ex partibus Hispaniarum aduenisse, "had come from Spain". ${ }^{62}$ The giant's geographic identity, combined with his grotesque corporeality, operating in the context of the $D G B$ 's use of Spain as a point of delimitation for Arthur's established European empire, points to the giant's racialization. The specter of the menacing Other, particularly the Muslim, operates in the giant

\footnotetext{
$58 \quad D G B, \mathrm{x} .163 .1-11$.
}

$59 D G B, \mathrm{x} .163 .10-11$.

6o Arthur's duel with Frollo is not racialized as is his battle with the giant of Mont-Saint-Michel, but narrative parallels are evident. $D G B, \mathrm{X} .155 .25 \mathrm{O}-305$.

61 See Cohen, "Race", pp. 109-10; G. Guzman, "Reports of Mongol Cannibalism in the Thirteenth Century”, in S.D. Westrem (ed.), Discovering New Worlds: Essays on Medieval Exploration and Imagination, New York, 1991, pp. 31-68; D.H. Strickland, Saracens, Demons, Jews: Making Monsters in Medieval Art, Princeton, 2003; Heng, Empire of Magic, pp. 23 and 36-37; Warren, History on the Edge, p. 34; S. Huot, Outsiders: The Humanity and Inhumanity of Giants in Medieval French Prose Romance, Notre Dame, 2016, p. 8; Whitaker, "Black Metaphors", pp. 169-93.

$62 \quad D G B$, X.165.33; 33-34. On the term "Saracen", see S. Rajabzadeh, "The Depoliticized Saracen and Muslim", Literature Compass 16:9-10 (2019), 1-8. 
of Mont-Saint-Michel. For Geoffrey and his readers, the "Saracen" was a racial type, bound up in religious, ethnic, and geographic identities. In a historical text concerned with wondrous natural phenomena and deeds, Geoffrey offers us a larger-than-life iteration of the Muslims populating Lucius's army. This figure of alterity, unlike the Europeans conquered and integrated into Arthur's empire, must be extinguished altogether.

This giant also carries associations with the first giant to appear in the $D G B$, Goemagog of Britain. According to Geoffrey, Britain was populated with barbaric giants before Brutus and his people arrived, whose central purpose in the $D G B$ is to provide an indigenous race for the Trojans to conquer, cementing British identity as an imperial force with which to be reckoned. (Indeed, as Michael Faletra shows in this volume, Geoffrey's giants are a race designed to be colonized). Goemagog is a spectacle of physical alterity to the noble British leaders Brutus and Corineus. Geoffrey's description goes as thus: "One of these Cornish giants was a monster called Goemagog, twelve cubits tall and so strong that he could loosen and uproot an oak tree as if it were a twig of hazel."63 Goemagog's corporeal form is as impressive in death as it was in life; after Corineus wrestles with him and casts him off a sea cliff, "he was torn into a thousand pieces and stained the sea red with his blood." ${ }^{\prime 4}$ This intensely embodied giant establishes a pattern of giants operating as racialized bodies in the $D G B$. In naming his first giant, Geoffrey taps into a well-established literary tradition of Gog and Magog. These unclean tribes of indefinite origins operated as eschatological specters for Geoffrey's audience. Biblical, classical, and Arabic sources describe Gog and Magog as monstrous races lurking in the Caucasus mountains, only temporarily imprisoned there by a massive wall and/or God's will. ${ }^{65}$ The $D G B$ harnesses these references for a learned, Latinate audience and presents the giant Goemagog as a racial body requiring extermination if a European empire is to succeed.

Gog and Magog have been associated with different groups throughout history, leading to the question of how Geoffrey and his audience may have read

$63 D G B$, i.21.469-72: "Erat ibi inter ceteros detestabilis quidam nomine Goemagog, staturae duodecim cubitorum, qui tantae uirtutis existens quercum semel excussam uelut uirgulam corili euellebat."

$64 \quad D G B$, i.21 486-87: "in mille frustra dilaceratus est et fluctus sanguine maculauit."

65 See A.R. Anderson, Alexander's Gate, Gog and Magog and the Inclosed Nations, Cambridge, MA, 1932, for a full, if dated, study of the tradition of Alexander's encounter with the tribes of Gog and Magog. For biblical references to Gog and Magog, see Ez. 38 and 39 and Rev. 2o. For Arabic references, see The Qurāan: New Annotated Translation, trans. A.J. Droge, Sheffield, 2013, 18:92-98 and Ibn Fadlān, Ibn Khurradādhbih on Sallām the Interpreter and Alexander's Wall 844, trans. P. Lunde and C. Stone, Ibn Fadlān and the Land of Darkness: Arab Travellers in the Far North, London, 2012, pp. 99-104. 
Goemagog. ${ }^{66}$ Ultimately, the ambiguity characterizing Goemagog's identity as it relates to Geoffrey's contemporary audience is generative. Goemagog's fundamental corporeal and cultural alterity harnesses the concept of racial difference to portray monstrosity. The giant poses a racial alterity on the very land to which he is indelibly tied and deserves a highly public extermination in service to the new empire forming in Britain. For Geoffrey, indigeneity is a signifier of racial inferiority, one from which he distances the Welsh and other worthy cultures. ${ }^{67}$

Goemagog serves as an important cognitive precedent for the reader of the $D G B$, bringing his valences of meaning to bear upon the unnamed giant of Mont-Saint-Michel. Like Goemagog, the unnamed giant is impossibly, grotesquely embodied. He kidnaps and attempts to rape a maiden. When she perishes of terror, rather than submit to the giant's attack, the giant sexually assaults her elderly attendant. When Arthur and his knights approach him, the giant is revealed to be as repugnant as the stories about him would suggest. Indeed, he is massively, repulsively corporeal: "The monster was by the fire, his mouth smeared with the blood of half-devoured pigs, some of which he had eaten, some of which, fixed on spits, he was roasting over coals." ${ }^{68}$ Medieval giants are not human, nor fully inhuman; they are a manifestation of a racial fantasy, wherein racial difference is marked clearly upon a body and can be understood and manipulated by a hegemonic power. Geoffrey's giants signify undefined racial alterity, obviated as both giants are slain by supreme figures of Euro-Christian British excellence.

After dealing with the Spanish giant, Arthur moves on to deal with Lucius and his pan-Asian and African army. As Arthur's men slash through the enemy,

66 Tatlock, $L H B$, p. 5o, notes that many early medieval writers discuss Magog, son of Japhet, and Gog and Magog as creatures shut up in the Caucasus mountains, to be released at some apocalyptic moment in the future. The legend is likely of Jewish origin and was picked up by Isidore, Nennius, Bede, and Haimo of Halberstadt, to name a few writers. Tatlock also notes that these mysterious figures have been interpreted as Scythians, Goths, Tartars, Turks, and Muslims. Tatlock concludes, "At any rate for a thousand years they were identified with various barbarous peoples who were threatening Christendom" (p. 54). Tatlock also stated that there is no reason to believe that Geoffrey's giants have anything to do with any of these peoples (p. 55).

67 For an introduction to the concept of indigeneity, as it intersects with Spivak's notion of subalternity, see J.A. Byrd and M. Rothberg, "Between Subalternity and Indigeneity: Critical Categories for Postcolonial Studies", Interventions: International Journal of Postcolonial Studies 13:1 (2011), 1-12. On medieval indigeneity, see A. Miyashiro, "Our Deeper Past: Race, Settler Colonialism, and Medieval Heritage Politics”, Literature Compass 16:9-10 (2019), $1-11$.

$68 D G B$, x.165.74-76: "Aderat autem inhumanus ille ad ignem, illitus ora tabo semesorum porcorum, quos partim deuorauerat, partim uero uerubus infixos subterpositis prunis torrebat." 
we are reminded of British racial superiority through a statement formulated in religious terms. Arthur personally kills two non-Christians, one of the last moments of the battle which Geoffrey narrates in detail: "He cut off the heads of two kings who were unlucky enough to meet him, Sertorius of Libya and Politetes of Bithynia, and dispatched them to hell." ${ }^{69}$ Not only are these men unable to resist Arthur's relentless attacks, they do not even die honorable deaths in battle. As Arthur and his superior British race press forward against the African and Asian troops of Lucius, Geoffrey pauses to remind his readers that there is a fundamental racial-religious rift between the two sides. This castigation operates in religious terms, but is accompanied by a racial stereotype pointing to Britons' perception of non-Europeans as essentially different.

This racist stereotype is embedded in multiple narrative layers. The rallying speech which Arthur uses to spur on his pan-European army focuses largely upon the wrongdoings of the Romans, who he characterizes as semiviros, "effeminates". ${ }^{70}$ Arthur places an imagined insult against of the Britons in their mouths, ventriloquizing for rhetorical effect: "Clearly they considered you to be as cowardly as easterners when they planned to exact tribute from your country and make you slaves." ${ }^{71}$ By having Arthur himself vocalize a racist stereotype, Geoffrey gives prominence and credence to the convention of portraying peoples of the East as racially inferior. In essence, Arthur's rallying speech appeals to a racial stereotype rooted in geohumoral essentialism. While Geoffrey's text is radical in its portrayal of European racial politics, it makes use of conventional, contemporary beliefs about races outside Christian Europe to elevate the status of the Britons within the European world.

Perhaps Geoffrey's most radical intervention in the racial discourse of 12thcentury Britain is his denigration of the Saxons, assigning to them racializing stereotypes which his contemporaries assign to the Welsh. In postcolonial terms, Geoffrey relegates the Saxons to what we might label subaltern status. ${ }^{72}$ While hybridity operates as a productive possibility across some racial divides within the $D G B$, it does not apply to barbarians like the barbarian Saxons. For Geoffrey, some European races are fundamentally flawed. The Picts and Scots, for example, are internal foreigners who are little more than pests in the $D G B$.

$69 \quad D G B$, X.174.434-36: "Duos reges, Sertorium Libiae Bithiniaeque Politetem, infortunium ei obuios fecit, quos abscisis capitibus ad Tartara direxit."

$70 \quad D G B$, x.169.284. Accusations of effeminacy are commonplace in many racializing rhetorics.

$71 D G B, \mathrm{x} .169 .278-8$ o: "Sane orientalium gentium segnitiam in uobis esse existimabant dum patriam uestram facere tributariam et uosmet ipsos subiugare affectarent."

72 In addition to Spivak on the subaltern, see R. Guha, Writings on South Asian History and Society, Delhi, 1984, and D. Chakrabarty, Provincializing Europe: Postcolonial Thought and Historical Difference, new ed., Princeton, 2008. 
It is the Saxons, however, who seem to be the most fundamentally flawed group in Geoffrey's text. The text fixates not only on their religion, but on their peculiar language and treacherous character, established by their May Day slaughter of Britons, and reiterated throughout the text. ${ }^{73}$ This portrayal elevates the history of the Britons and simultaneously justifies later Norman occupation of the island, since the glorious Britons have fallen from power and the Saxons are deeply undeserving of their erstwhile hegemony. While scholarship suggests that the binary between Saxons and Normans disappeared quickly after the Conquest, with any racial antagonism being subsumed quickly by intermarriage and linguistic assimilation, Geoffrey's text is relatively uninterested in Anglo-Norman hybridity. ${ }^{74}$

The $D G B$ rejects outright the Anglocentric orientation of historiography in central medieval Britain, moving beyond disinterest into outright antipathy. ${ }^{75}$ The Saxons' introduction into the narrative establishes them not only as pagans, but as a menacing racial alterity in Britain. Saxon occupation of Britain is due to Vortigern's infamous treachery, which paves the way for Horsa and Hengist to establish a Saxon presence in Britain. When Vortigern welcomes the brothers to his court, he questions them in such a way that allows Geoffrey to provide an ethnic portrait for the Saxons in their own voices. Hengist immediately explains that Saxon warships have come to Britain because of a consuetudo, "custom", of his people, which dictates that overpopulation be relieved by sending men abroad. ${ }^{76}$ Hengist then describes his deos patrios, "native gods", establishing immediately that these men have peculiar ethnic and religious practices. ${ }^{77}$ Geoffrey suggests it would be right to be wary of these foreigners, especially when they request land. Vortigern hesitates, saying "I am forbidden to grant such favours because you are foreigners and pagans, and I am not yet well enough acquainted with your character and customs to treat you like my fellow countrymen."78 For Geoffrey, xenophobic policies are necessary and useful when deployed against the Saxons, as opposed to the Normans. However, Vortigern is persuaded and ceases to resist the Saxons entirely once he meets

$73 \quad D G B$, vi.104.

74 This orientation operates in contrast to many of Geoffrey's contemporaries, such as William of Malmesbury and Henry of Huntingdon, who were hybrids themselves. See Cohen, Hybridity, pp. 43-76.

75 See Thomas's chapter in this volume; on Geoffrey's anti-Bede strategies, see Cohen, Hybridity, p. 65 .

$76 \quad D G B$, vi.98.262.

$77 \quad D G B$, vi.98.277.

$78 D G B$, vi.99.320-22: "Prohibitus sum huiusmodi donaria uobis largiri, quia alienigenae estis et pagani nec adhuc mores uestros et consuetudines agnosco ut uos conciuibus meis parificem." 
Hengist's daughter Ronwein. Satan, working through the pagan Saxons, causes Vortigern to be enchanted by lust for Ronwein, entrenching him in Saxon company and culture. ${ }^{79}$

For Geoffrey, linguistic difference between the Britons and Saxons is a key tool for illustrating racial difference, reflecting Isidore's statement that Germanic racial characteristics are represented in their language..$^{80}$ Indeed, Kim's theory of spoken language as a racializing mechanism holds true in the $D G B$. The Saxon language is the only "foreign" language spoken in the $D G B$, outside of Latin and Latinized versions of place-names, and it is entangled with the characteristic treachery of the Saxon race. Ronwein's greeting to Vortigern, "Lauerd king, wassail", and the traditional response of "drincheil", seal Vortigern's love for the Saxons. ${ }^{81}$ His initiation into the speech and customs of the newcomers exposes Britain to a centuries-long foreign occupation. Ronwein's role in the drinking ritual by which Vortigern ensnares himself in Saxon conquest echoes through the narrative. After Vortigern's exile, Ronwein reprises her role of offering drink to men. This time, she commits murder with poison, ridding herself of her stepson Vortimer. ${ }^{82}$

The menacing Saxon language appears a second time, reiterating its association with betrayal and murder. Assisted by Ronwein as an informant of Vortigern's movements, Hengist invites the British king and people to a May Day parlay. In the $D G B$ 's most dramatic scene of Saxon treachery, the two sides gather and Geoffrey develops narrative tension by revealing that "Hengist, resorting to unheard-of treachery", had instructed the Saxons to prepare to slaughter the unsuspecting Britons. Indeed, "When he saw that the moment was ripe for treachery, Hengist shouted, 'nimet oure saxas' and immediately

$79 D G B$, vi.1oo. For more work on Vortigern's lust for the exotic pagan Ronwein, see Warren, History on the Edge, esp. p. 44. On colonizing Western feminization and eroticization of the East, see Heng, Empire of Magic, pp. 181-238. See also A. Burge, Representing Difference in the Medieval and Modern Orientalist Romance, New York, 2016.

80 The inmanitas barbariae, "monstrosity of barbarism", of Germanic peoples gives a fearsome quality even to their names. See Isidore of Seville, Etymologies Ix.ii.97, ed. Lindsay, trans. Barney et al.

$81 \quad D G B$, vi.100.346-52.

$82 D G B$, vi.102. Geoffrey develops exceptionally positive portrayals of female leadership, perhaps due to his support for Empress Matilda, mother of the Plantagenet dynasty and half-sister of his sometimes-patron Robert of Gloucester. The Saxon Ronwein is largely an exception to this general trend in the $D G B$ and $V M$. See F. Tolhurst, Geoffrey of Monmouth and the Feminist Origins of the Arthurian Legend, New York, 2012; ead., Geoffrey of Monmouth and the Translation of Female Kingship, New York, 2013; and her contribution to this volume. 
seized Vortigern and held him by his robe."83 The Saxons follow suit and slit the throats of 45 o unarmed British leaders, then banish Vortigern to Wales.

Both before and after their conversion, the Saxons are essentialized as treacherous and wicked. Their introduction to the narrative and the events leading to their establishing a Saxon presence in Britain portray the newcomers as evil foreigners, essentially corrupt in racial terms. This portrayal continues through the text. When the Saxons are unable to kill Uther Pendragon in battle, they develop a new strategy: "Resorting to their customary treachery, they plotted to kill the king by deceit." ${ }^{84}$ Following the example of Ronwein, some nefandi proditores, "wicked traitors", poison Uther's spring, a fraude, "treacherous deed", which kills the king and 100 other men. ${ }^{85}$ After Arthur routs the Saxons, who pledge hostages and leave Britain for Germany, the Saxons turn and attack cities along the Severn. Arthur wonders at this facinus, "wickedness", and announces that "Since the wicked Saxons, true to their evil repute, refuse to keep faith with me", he will keep faith with God and avenge his countrymen. ${ }^{86}$ Mordred's betrayal of Arthur takes up the racialized valences of the concept of treachery. Like Lucius, who built an army of races outside Geoffrey's realm of acceptability, Mordred builds an army of Saxons, Scots, Picts, and Irish. With his army of racialized, inferior peoples, Mordred becomes tainted with the mark of treachery, as Geoffrey refers to him as ille nefandus, "the treacherous" Mordred. ${ }^{87}$ After Arthur's death, Saxon treachery sees the island overrun by Africans: "Thanks to the Saxons' treachery, Gormundus and a hundred and sixty thousand Africans crossed to Britain, which was being laid completely waste, on the one side by the faithless Saxons, and on the other by the continual civil wars waged by its own citizens." 88 African alterity arrives in Britain in force, but it is the characteristic Saxon proclivity for treachery that results in slaughter throughout Britain. Of course, the innate Welsh tendency toward civil war is another problem altogether, one addressed below. However, while

$83 D G B$, vi.104.459-67: "Hengistus, noua proditione usus ... Ut igitur horam proditioni suae idoneam inspexisset Hengistus, uociferatus est 'nimet oure saxas' et ilico Vortegirnum accepit et per palliam detinuit."

$84 D G B$, viii.142.598-99: "Proditioni etiam solitae indulgentes, machinantur qualiter regem dolo interficiant."

$85 \quad D G B$, ix.142.598, 6o6, 608 .

$86 D G B$, ix.146.83; 89-9o: "Quoniam impiissimi atque inuisi nominis Saxones fidem michi dedignati sunt tenere."

$87 \quad D G B$, xi.178.72.

$88 D G B$, xi.184.125-28: "Exin proditione eorum cum centum sexaginta milibus Affricanorum ad Britanniam transfretauit, quam in una parte mentitae fidei Saxones, in alia uero ciues patriae, ciuilia bella inter se assidue agentes, penitus deuastabant." 
the Britons are falling from grace, the Saxons remain inherently and unchangeably faithless.

Geoffrey's vision of a Saxon-African alliance draws heavily from William of Malmesbury's account of the Danish Guthrum's baptism. ${ }^{89}$ It seems possible that the biblical metaphor which William had drawn upon to make the point that a pagan Dane's proclivities are no more changeable than the color of an Ethiopian's skin could have inspired Geoffrey's engagement with race at this moment. Of course, while William's Gormundus is metaphorically darkskinned, Geoffrey's Gormundus is raced more concretely. His African identity (or geographic race) likely signals a "Saracen" identity, a racial-religious category that was often depicted through black or dark skin. ${ }^{90}$ While William's Gormundus was linguistically and culturally alien, Geoffrey places his Gormundus's alterity upon the character's skin.

However, African occupation of Britain is short-lived, as King Gormundus gives Loegria to the Saxons, "through whose treachery he had landed". ${ }^{91}$ British forces attempt to expel the Saxons, and when an opportunity for co-existence arises, the British king of Demetae, Margadud, reminds King Caduallo that "since it has been your intention to drive the entire English race from Britain's shores, why change your mind and permit them to live among us in peace? ... Ever since they first entered this land, the Saxons have always plotted to betray our race." ${ }^{\prime 2}$ The pathos-filled speech of the exiled British King Cadualadrus recalls the uersutae proditionis, "deceitful treachery", of the Saxons, reminding Geoffrey's readers that the Saxons did not win Britain through noble means, and rendering their occupation of the island illegitimate. Cadualadrus, on his way to exile in Armorica, calls out for all the undeserving races who attempted to control Britain to return. The Romans, Scots, Picts, and ambrones Saxones, "ravenous Saxons", may as well return, since Britain is now uninhabited.

Even after Saxon conversion, Geoffrey's characterization of the Saxons is uncomplimentary. In the only episode of the $D G B$ which portrays Saxon piety, Oswald, king of Northumbria, raises the cross and commands his soldiers to

89 William of Malmesbury, Deeds of the English Kings ii.121.6, ed. and trans. R.A.B. Mynors, completed by R.M. Thomson and M. Winterbottom, William of Malmesbury: Gesta Regum Anglorum, The History of the English Kings, 2 vols., Oxford, 1998-99.

9o Cohen gives Geoffrey's main source for Gormundus as the Old French Gormont and Isembart, in which Gormont is a Saracen invading England; see "Race", p. 110.

$91 \quad D G B$, xi.186.157: "quorum proditione applicuerat".

$92 \quad D G B$, xi.200.481-88: "quoniam omne genus Anglorum te ex finibus Britanniae expulsurum proposuisti, cur a proposito tuo diuertens ipsos inter nos in pace manere pateris ... Saxones ergo, ex quo primum patriam nostrum ingressi sunt, semper insidiantes gentem nostrum prodiderunt." 
pray with him against the British king Caduallo and his Saxon ally, Peanda. Oswald wins the day, but is killed soon after. ${ }^{93}$ For a narrative moment, Caduallo becomes an unsympathetic character, torturing men, women, and children in an attempt at genocide. ${ }^{94}$ This reversal of Saxon and British characteristics is temporary, however. After the Britons lose their sovereignty altogether, the Saxons indulge in their continuum morem, "unfailing custom", and invite hordes of their Germanic countrymen to immigrate to Britain..$^{95}$ This nefandus populus, "wicked people", surge into the once-noble island. For Geoffrey, Saxon occupation of Britain is unjustified, regardless of the Saxon religion. The Saxon race is inherently flawed, regardless of British behavior.

Because some races are innately lower than others within Geoffrey's racial schema, it is simply impossible for Saxon-Briton mixing to work within his model of positive hybridity. As the text winds to a close, the potential for a peacefully multiethnic Britain, incorporating Britons and Saxons, is definitively foreclosed by the tale of Edwin and Caduallo. ${ }^{96}$

These two men, one Saxon and one Briton, respectively, are princes. Raised together in the relatively neutral territory of Armorica, Edwin and Caduallo are foster brothers who take up their thrones in mutual amicitiam, "friendship". ${ }^{97}$ However, this interracial friendship comes to a swift end when Edwin asks Caduallo's permission to hold a royal crowning ceremony for himself in Northumbria. This move would signify full equality between the two kings, with Southern and Northern Britain fully divided between Saxon and British rulership. Caduallo seems amenable to the arrangement, but a queer intimacy with a fellow Briton intervenes in Caduallo's queer interracial relationship with a Saxon.

Geoffrey creates a scene of physical intimacy between Caduallo and his nephew, Brianus, while British leaders consider Edwin's request. During talks at the River Duglas, "elsewhere by the river Caduallo was reclining in the lap of a nephew of his, called Brianus." ${ }^{98}$ This idyllic scene marks a narrative shift from sparse, chronicle-like prose to a "close-up shot" on the faces of the two men. While counselors debate among themselves, "Brianus wept and the tears he shed dripped onto the king's face and beard. Caduallo thought that rain

\footnotetext{
$93 \quad D G B, x i .199$.

$94 D G B, x i .198$.

$95 \quad D G B, x i .204 .551$.

96 Of course, this portrayal is not necessarily based on historical truth. See L. Brady, Writing the Welsh Borderlands in Anglo-Saxon England, Manchester, 2017, esp. p. 27.

$97 \quad D G B$, xi.191.246.

$98 D G B$, xi.191.252: "iacebat Caduallo in alia parte fluminis in gremio cuiusdam nepotis sui, quem Brianum appellabant.”
} 
was falling and raised his head, but when he saw the youth was weeping, he asked the reason for his sudden sadness."99 Brianus's tears on Caduallo's head, which reclines on Brianus's lap, attest to the intimacy of this relationship. When Brianus reveals that the source of his sorrow is the degradation of the British people at the hands of the Saxons, Caduallo is entirely persuaded to deny Edwin's request for full sovereignty in Northumbria.

Geoffrey provides no clear moral commentary upon this decision. While the peace enjoyed between Caduallo and Edwin was portrayed positively, so is the queer relationship between Caduallo and Brianus. Because it is Brianus who is ultimately responsible for the concluding events of the $D G B$, it is possible that his character sheds light on how the ending of the $D G B$ functions in racial terms. Brianus's tear-filled speech, delivered as he cradles his uncle's head, is portrayed sympathetically. The image Geoffrey conjures in this moment is that of the Virgin Mary, cradling Christ's head and bathing him in her tears, like an early iteration of the Piéta. Brianus is oriented as the long-suffering helpmeet; however, rather than using his intimate relationship with the king to weave peace, he makes an emotional appeal for war. The evocative nature of the scene carries with it an implicit approval of Caduallo's determination to make war on the Saxons.

The physical and emotional intimacy between Caduallo and Brianus intensifies during the war. After a shipwreck at the isle of Guernsey, Caduallo falls ill with "such grief and anger at the loss of his comrades that he refused to eat and lay sick in his bed for three days and nights" ${ }^{100}$ Caduallo's love for his men is so intense that the loss of his soldiers in a shipwreck causes him intense physiological pain. Because the only food Caduallo desires is game, Brianus goes hunting the length and breadth of Guernsey with no success. In a gesture of erotic, Christ-like self-sacrifice, Brianus "cut and removed a slice from his own thigh, which he roasted on a spit and presented to the king as venison".101 Brianus's meat revives his beloved king, who proclaims the meal to be the most delicious he had ever tasted.

$99 D G B$, xi.191.254-56: "fleuit Brianus lacrimaeque ex oculis eius manantes ita ceciderunt ut faciem regis et barbam irrorent. Qui imbrem cecidisse ratus erexit uultum suum uidensque iuuenem in fletu solutum causam tam subitae maesticiae inquisiuit."

$100 \quad D G B$, xi.193.310-11: "tantus dolor et ira ob amissionem sociorum suorum ita ut tribus diebus et noctibus cibo uesci aspernaretur ac in lecto infirmatus iaceret."

$101 D G B$, xi.193.318-20: "sscidit femur suum et abstraxit inde frustum carnis parataque ueru torruit illud et ad regem pro uenatione portauit." 
Racially speaking, cannibalism typically places a human race on the far end of the spectrum between man and monster. ${ }^{102}$ For Isidore, discussion of the peoples of the world begins in the Mediterranean and Europe, then moves east and south, proceeding as far as the Trochodites, Pamphagians, Icthyophagians, and Anthropophagians (cannibals), before reaching the Antipodes. ${ }^{103}$ In fact, for Isidore, the Anthropophagians seem to be the most foreign race possible, since the Antipodean people, according to him, are imaginary. ${ }^{104}$ However, Geoffrey portrays Brianus's offering of his thigh for Caduallo's consumption as a novel, selfless action. Brianus takes on feminine valences of Christian sacrifice, resembling the maternal pelican who pierces her own breast and revives her young with her own blood. ${ }^{105}$ Whether he is portrayed as Marian or Christ-like, Brianus is a figure of holy femininity whose central goal is the promotion of Caduallo and his British subjects. When the $D G B$ poses the question of whether Saxon and British alliance is possible and desirable, the holy Brianus intervenes with persuasive homoerotic, intrafamilial, and intraracial solutions to the problem of British sovereignty.

Brianus's final, valiant deed is a racially-charged assassination. In the text's third negative reference to Spain, we learn that the Saxon Edwin, echoing the Saxon recruitment of the African Gormundus, has hired a Spanish augur named Pellitus. ${ }^{106}$ Aided by his sister, who had been kidnapped by Edwin, Brianus locates the augur and kills him swiftly. ${ }^{107}$ The Saxons lose their advantage: Pellitus's exotic, esoteric Spanish education.

The deeds of Caduallo and Brianus establish the impossibility of a SaxonBriton alliance, since their intimate relationship supersedes the fraternal bond which Caduallo and Edwin once enjoyed. The final king of the Britons is Caduallo's son Cadualadrus, whose own mixed parentage is provided as an afterthought. Geoffrey states that "His mother was Peanda's paternal sister, but by a different mother, belonging to the noble line of the Gewissei." 108 Intermarriage between the royal Saxons and Britons comes to naught, as did

\footnotetext{
102 On medieval race as a spectrum, see S.C. Akbari, Idols in the East: European Representations of Islam and the Orient, 1100-1450, Cornell, 2009. On cannibalism, see Heng, Empire of Magic.

103 Isidore of Seville, Etymologies IX.ii.120-33.

104 Isidore of Seville, Etymologies Ix.ii.132, ed. Lindsay: "Anthropophagi gens asperrima sub regione Siricum sita, qui quia humanis carnibus vescuntur, ideo anthropophagi nominantur", "Anthropophagians are a very rough tribe situated below the land of the Sirices. They feed on human flesh and are therefore named 'maneaters', trans. Barney et al.

105 Isidore, Etymologies XII.vii.26, ed. Lindsay.

$106 \quad D G B$, xi.193.

$107 \quad D G B$, xi.197.

$108 D G B$, xi.202.516-18: "Mater eius fuerat soror Peandae patre tantum, matre uero diuersa, ex nobili genere Gewisseorum edita."
} 
the fosterage of Edwin and Brianus. An angelic voice sends the last great Briton king, Cadualadrus, to be numbered among the saints and to await the prophesied return of the Britons. ${ }^{109}$ For Geoffrey, it is not possible for Saxons and Britons to mix productively. While hybridity functioned in the deep past, facilitating the inception and growth of British civilization on both island and continent, it fails in the end.

\section{4}

\section{Conclusion}

Geoffrey famously concludes the $D G B$ with a castigation of the Welsh: "As their culture ebbed, they were no longer called Britons, but Welsh, a name which owes its origin to their leader Gualo, or to queen Galaes or to their decline."110 In characteristic fashion, Geoffrey looks to etymological reasons for the name "Welsh" and points to its derivation from the Old English term wealh, which varies in meaning but is often taken to mean "foreigner". ${ }^{111}$ For Geoffrey, race is highly malleable, with the exception of some peoples. This malleability serves a highly useful purpose: that of new colonial movements in Britain.

Although the Saxons cultivate the land of Loegria, they came by the land through wickedness and treachery, traits which Geoffrey's contemporaries attributed mainly to the Welsh. By transferring these racialized traits to the Saxons and elevating the history of the Welsh, Geoffrey paves the way for the Norman colonization of Britain. In fact, Geoffrey's single, direct address to the Welsh reads as an exhortation of his own people, thus using the ancient Welsh as a metaphorical vehicle for his modern target audience: "Why, you slothful race, weighed down by your terrible sins, why with your continual thirst for civil war have you weakened yourself so much by internal strife? You once subjected far-off realms to your power, but are now unable to protect your land, wives and children from your foes, so that you resemble a vineyard once good, but now turned sour."112 This long speech reiterates again and again the

$109 \quad D G B, x i .205$.

$110 D G B$, xi.207.592-94: "Barbarie etiam irrepente, iam non uocabantur Britones sed Gualenses, uocabulum siue a Gualone duce eorum siue a Galaes regina siue a barbarie trahentes."

111 See J. Bosworth, “An Anglo-Saxon Dictionary Online”, ed. T.N. Toller et al., Prague, 2010, <http://bosworth.ff.cuni.cz/o34770> (accessed 31 May 2018), s.v. wealh, I: "a foreigner, properly a Celt (cf. the name Volcae, a Celtic tribe mentioned by Caesar), Walch, barbarus".

$112 D G B$, xi.185.141-45: "Quid, ociosa gens pondere inmanium scelerum oppressa, quid semper ciuilia proelia siciens tete domesticis in tantum debilitasti motibus, quae cum prius longe posita regna potestati tuae subdidisses nunc uelut bona uinea degenerata in amaritudinem uersa patriam, coniuges, liberos nequeas ab inimicis tueri?" 
evils of civil war and the failure of imperial designs in light of internal discord. Indeed, it seems that many of Geoffrey's complaints against the Britons/Welsh operate as appeals to his contemporary Norman audience. For Geoffrey, who completed the $D G B$ in 1136 under the patronage of Robert of Gloucester, a key player in the English civil war of $1135^{-57}$, internal strife was a major problem. Because of these well-documented concerns over England's sovereignty, the $D G B$ 's portrayal of race cannot be extricated from its historical context. While the text's criticisms of Welsh disunity have been read as anti-Welsh, they seem to be anti-civil war, speaking to the chaos-inducing wars between Robert of Gloucester, the Empress Matilda, and Stephen of Blois. For Geoffrey, imperialism functions at its best when intermarriage allows the conquerors to mix seamlessly with the native population. ${ }^{113}$ While some races are unworthy of such mixing, the glorious heritage of the Welsh make them worthy of hybridization with their new conquerors.

Although hybridity can be an important facilitator of empire, there are subaltern peoples who exist beyond the pale of racial acceptability in Geoffrey's world. By showing who these peoples are, and replacing the Welsh with the Saxons as internal European Other, Geoffrey negotiates the Welsh into a relatively elevated position in the growing Norman empire. Furthermore, in a tripartite world, the $D G B$ develops an early model of Eurocentric history, orienting Britain as prestigious enough to take up an influential role in European government. In turn, Europe emerges as the central point of Geoffrey's history. Ultimately, Geoffrey replaces Isidore's model of geohumoral race with the concept of race as situational and malleable, legitimizing the process of hybridization, though excepting peoples beyond the pale. The various racial boundaries both deconstructed and established in the $D G B$ enjoyed long afterlives, with Geoffrey's foundational text paving the way for the development of the homo europaeus ${ }^{114}$ and for a nascent imperial British consciousness.

\footnotetext{
113 It is possible that Geoffrey's positive attitude toward intermarriage is directly related to the marriages of the Empress Matilda. See M. Chibnall, The Empress Matilda: Queen Consort, Queen Mother and Lady of the English, Oxford and Cambridge, MA, 1991.

114 Heng, Invention, p. 24.
} 